\title{
Study of the leisure influence on attitude for leisure and mental health in a sample of portuguese seniors
}

\author{
Pedro Belo, Ricardo Pocinho \& Esperanza \\ Navarro-Pardo
}

\begin{abstract}
Increased human longevity has been attributed to technological and medical advances, as well as improved hygiene and nutritional conditions, access to health care, changes in eating habits and cognitive development strategies (Osório, 2007). The present study examined the influence of leisure actions in the psychological well-being, leisure attitude and distress of seniors. The sample consisted of 403 participants (37,2\% male; $62,8 \%$ female). Concerning the perception of health condition, $82,6 \%$ subjects were considered independent and $17,4 \%$ participants were considered dependent. The instruments used were the $\mathrm{MHI}$ (Ribeiro, 2001) and the LAS (Freire \& Fonte, 2007). Main results exposed that participants in leisure activities presented high level of well-being and attitude for leisure $(p<0,05)$. Seniors that present big levels of distress indicated an intention to participate in activities of leisure that aided to decrease that symptom. Results showed that seniors health perception influenced the practice of a leisure activity [Hotelling's Trace $=0,077$; $\left.F_{(3 ; 341)}=8,733 ; p=0,00\right]$. The results found helped to recognize the necessity, and importance, of leisure activities between seniors.
\end{abstract}

Keywords:

well-being; mental health; leisure; elderly. 


\section{Étude de l'influence des loisirs sur l'attitude pour les loisirs et la santé mentale dans un échantillon de personnes âgées portugaises}

Resumé: L'augmentation de la longévité humaine a été attribuée à des avancées technologiques et médicales, ainsi qu'une amélioration de l'hygiène, des conditions de nutrition, l'accès aux soins de santé, le changement dans les habitudes alimentaires, ou les stratégies de développement cognitive (Osório, 2007). Cette recherche visait à étudier l'effet des activités de loisirs pour le bien-être psychologique, l'attitude face aux loisirs et la détresse des personnes âgées. L'échantillon a été composé par 403 participants (37,2\% hommes; $62,8 \%$ femmes). En ce qui concerne la perception de l'état de santé, $82,6 \%$ des sujets ont été considérés indépendants, tandis que 17,4\% participants ont été considérés dépendant. Les instruments utilisés étaient le MHI (Ribeiro, 2001) et la LAS (Freire \& Fonte, 2007). Les principaux résultats ont montré que les sujets sont impliqués dans des activités de loisirs de niveau élevé présentent du bien-être et de l'attitude pour les loisirs $(p<0,05)$. Les participants qui éprouvent des niveaux élevés de détresse, cherchent à s'engager dans des activités de loisirs ce qui les aident à réduire ce symptôme. II a été constaté que la perception de la santé des personnes âgées influence la pratique d'une activité de loisirs [Hotelling's Trace = 0,077; $\left.\mathrm{F}_{(3.341}=8,733 ; \mathrm{p}=0,00\right]$. Les résultats obtenus ont aidé à intention reconnaître la nécessité et l'importance des activités de loisirs chez les personnes âgées.

Mots-clés: bien-être; santé mentale; loisirs; personnes âgées.

\section{Estudo da influência do lazer na atitude para o lazer e na saúde mental numa amostra de séniores portugueses}

Resumo: O aumento da longevidade humana tem sido atribuído aos avanços tecnológicos e médicos, assim como a uma melhoria das condições de higiene, condições de nutrição, acesso aos cuidados de saúde, mudança nos hábitos alimentares, ou a estratégias de desenvolvimento cognitivo (Osório, 2007). O presente estudo analisou a influência das actividades de lazer no bem-estar psicológico, na atitude para o lazer e no distress dos idosos. A amostra foi composta por 403 participantes (37,2\% do sexo masculino e 62,8\% do sexo feminino). Quanto à percepção da condição de saúde, $82,6 \%$ dos indivíduos são independentes e 17,4\% dos participantes foram considerados dependentes. Os instrumentos utilizados foram o MHI (Ribeiro, 2001) e a LAS (Freire \& Fonte, 2007). Os principais resultados mostram que os participantes em atividades de lazer apresentaram alto nível de bem-estar e uma boa atitude para o lazer $(p<0,05)$. Os idosos que apresentam grandes níveis de distress indicaram a intenção de participar em atividades de lazer que ajudam a diminuir esse sintoma. Os resultados mostraram que a percepção de saúde dos idosos influenciou a prática de uma atividade de lazer [Hotelling's Trace =0,077; F ${ }_{(3: 341)}=8,733 ; \mathrm{p}=$ $0,00]$. Os resultados encontrados apoiam a necessidade e a importância das atividades de lazer na terceira idade. Palavras-chave: bem-estar; saúde mental; lazer; idosos.

\section{Estudio de la influencia del ocio en la actitud para el ocio y la salud mental en una muestra de ancianos portugueses}

Resumen: El aumento de la longevidad humana se atribuye a los avances tecnológicos y médicos, así como una mejora de la higiene, las condiciones de nutrición, acceso a la salud, el cambio en los hábitos alimenticios, o a estrategias de desarrollo cognitivo (Osório, 2007). Este estudio examinó la influencia de las actividades de ocio en el bienestar psicológico, la actitud para el ocio y en el distress de las personas mayores. La muestra consistió en 403 personas (37,2\% hombres y $62,8 \%$ mujeres). En cuanto a la percepción del estado de salud, el 82,6\% de los individuos son independientes y el 17,4\% de los participantes fueron considerados dependientes. Los instrumentos utilizados fueron el MHI (Ribeiro, 2001) y la LAS (Freire \& Fonte, 2007). Los principales resultados muestran que los participantes en actividades de ocio tenían un alto nivel de bienestar y una buena actitud para el ocio $(p<0,05)$. Las personas mayores que tienen niveles altos de distress han indicado su intención de participar en las actividades de ocio que ayudan a reducir este síntoma. Los resultados muestran que la percepción de la salud de las personas mayores influyó en la práctica de una actividad de ocio [Hotelling's Trace $=0,077 ; F_{(3 ; 341)}=8,733 ; p=0,00$ ]. Los resultados apoyan la necesidad y la importancia del ocio en la vejez.

Palabras clave: bienestar; salud mental; ocio; personas mayores. 


\section{Introduction}

The phenomenon of ageing is a positive occurrence for individuals and for societies that takes place as a consequence of economic and sociobiomedical progress. In this context, ageing can be studied through various perspectives and theories. The process is universal and experienced by everybody, however in different ways (FernándezBallesteros, 2008; Hawkins, Foose, \& Binkley, 2004; Korten et al., 1999; Schneider \& Irigaray, 2008).

This step of the life cycle can be a time of new achievements and continued development, both in the social, cognitive and cultural fields (Belo, Pocinho, \& Navarro-Pardo, 2016). Seems crucial and of high relevance the study of ageing as a specific stage of life cycle. For Belo, Pocinho and Navarro-Pardo (2016) this implicates an active and continuous balance enduring its impressiveness in the interaction between maturation, learning and senescence. A new idea about ageing emerged and a new design reflects the positive aspects of the third age, where is possible to explore the potential of actions and quality of life.

The involvements and information learned throughout life can be improved at this time. As a result, leisure plays an essential part in the process, once is perceived as a value for seniors and society (Brown, McGuire, \& Voelkl, 2008).

\section{Leisure, Distress and Well-Being}

Leisure is an important issue to characterize lifestyle. The activities of leisure stimulate patterns of satisfaction and pleasure, becoming a positive life experience, and a valuable indicator of quality of life (Freire, 2000). Positive experiences appeared to be a crucial aspect for leisure, once the activities promote a belief of time quality and wellbeing (Han \& Patterson, 2011). Castro and Carreira (2015) studied the role of leisure events in institutionalized elderly population. The results showed that bestowing a positive attitude toward leisure probably is influenced by past experiences, and determine the construction of beliefs and feelings. Multiple studies with seniors point out an evidence of a robust association (positive) between the involvement in activities of leisure and health (Ra, Na, \& Rhee, 2013; Westland, 1991).

Hawkins, Foose and Binkley (2004) revealed that a high involvement, or participation, in leisure actions is related with life satisfaction. It seems to have an important implication in promoting and increasing well-being in old age (Belo, Pocinho \& Navarro-Pardo, 2016; Heo et al., 2013; Ra, Na, \& Rhee, 2013). Leisure activities frequently take place in contexts of social relations, also providing benefits in health promotion. So, participation in leisure activities affects the relationship between positive social relations, physical and psychological well-being (Chang, Wray, \& Lin, 2014). The study 
of Cheung et al. (2009) with a sample of 65 years, or more, elders showed that high levels of participation in social and cognitive activities have an association with a higher quality of life (particular focus on physical and mental functioning, mental health and physical function). Glass et al. (1999) presented that both, participation in social activities and productive activities, are related with a low risk of mortality in aged population (Belo, Pocinho, \& Navarro-Pardo, 2016). Sun and Liu (2006) also show the relation presented in a sample of people aged 80 years or more, analyzing the relationship of three types of daily activities: social, active lonely and solitary sedentary. The results of the study propose that activities of solitary sedentary type are negative, but actions that need some physical effort or social relations are favorable to the individual, having impact on welfare, mental health and survival of the elderly (Sun \& Liu, 2006).

For Han and Patterson (2007), the relation found by leisure, health, and well-being has an enduring connection. Feeling a satisfying attitude through leisure participation (time spent reading, contact with nature, spend time alone visit other people, eating in the company and participation in religious groups) are defined as one of the most important benefits of leisure, and has been exposed to contribute to improve the quality of life (Han \& Patterson, 2007).

Chodzko-Zajko et al. (2009) bared that participation in leisure activities overtime protects against chronic and degenerative diseases contributing for well-being, while the inactive leisure, related to a sedentary lifestyle increases the risk for such health outcomes. Besides the perception that individuals have about past, present and future is a descriptor of their psychological well-being (Cohen, 2000).

How people spend their leisure time is a key factor in preserving psychological health. A physical activity (of leisure) is associated with decreased mortality from many physical illnesses and decreased risk of mental disorders, associated with an increase in life expectancy, but psychological distress may decrease the likelihood of engaging in leisure-time physical activities. Some outdoor leisure activity and physical activity were significantly correlated (negative association) with psychological distress (Toyoshima, Kaneno, \& Motohashi, 2016). People who do regularly outdoor leisure activities are significantly less likely to be psychologically distressed. Women who engaged regularly in physical activity were significantly less likely to be psychologically distressed (Toyoshima, Kaneno, \& Motohashi, 2016). Shah, Wadoo and Latoo (2010) reported that psychological distress has a significant impact not only on the person, but also on families. Mental disorders have a considerable impact on family members and can lead to a reduction in social activities, producing isolation sometimes. This can lead to the development of leisure new activities with the main objective of avoid negative impacts on life quality of older adults. For leisure these aspects are reflected not only in the level of knowledge of the socio-cognitive processes but also in the intervention, in the 
Belo, Pocinho \& Navarro-Pardo: Study of the leisure influence on attitude for leisure and mental health

definition of strategies of involvement in leisure activities and in adherence to opportunities structured and offered by the community (Fonte \& Freire, 2007).

\section{Method and Data Analysis}

The sample was (simple) random where participants were personally contacted and a confidentiality agreement was established with them. Subsequently, participants completed the protocol that was delivered. Each protocol questionnaire had standard instructions and participants were asked to respond under the option they felt was most relevant to them. It was clear to the participants that there were no right and wrong answers. After completing the set of questions, they were asked to return the questionnaires. Administration of the protocol lasted 25 minutes.

The study intends to determine the effect of leisure in distress and psychological well-being. Thus, it seems essential the analysis of the contribution that participation in leisure activities have on well-being of aged people. Putting in evidence the sociodemographic variables (covariables) that are significant, it will be used the Multivariate Analyses of Covariance (MANCOVA) conducted to examine differences between groups (Netter, Wasserman, \& Kutner, 1990). It was verified to examine differences between groups by controlling the influence of possible parasitic variables (covariates). Post-hoc test also was tested (Bonferroni adjustment for multiple comparisons).

\section{Instruments}

The research protocol administration will consist of a sociodemographic questionnaire the MHI-Mental Health Inventory (Ribeiro, 2001) and LAS-Leisure Attitude Scale (Freire \& Fonte, 2007).

\section{$\mathrm{MHI}$ - Mental Health Inventory}

The Mental Health Inventory (Ribeiro, 2001) is a questionnaire used for evaluating mental health issues: anxiety, depression, behavioral control, positive effect, and general distress. The Mental Health Inventory includes 38 items in which the participant uses a 5 or 6 -point Likert-style response. The 38 items are distributed by five scales (Anxiety with 10 items; Depression, with five items; Loss of Emotional / Behavioral Control, with 9 items; Positive Affect, with 11 items; Emotional Ties, with 3 items). In turn, these five subscales are grouped into two major sub-scales or dimensions that respectively measure the Distress and the Well-Being (Distress results from the grouping of the sub-scales of Anxiety, Depression, and Loss of Emotional / Behavioral Control; while Well-Being results from the combination of sub-scales Positive Affect and Emotional Ties). The total score is the sum of the values of the items that make up each 
scale. There are some items with reverse quote. This instrument helps in the measure of overall emotional functioning. Research has shown the existence of a positive (psychological well-being, positive mental health status) and another negative construct (psychological distress, negative mental health status). This type of measure is the more important when the objective is to evaluate health in general, or in the context of epidemiological studies (e.g., epidemiology of health), or in the evaluation of health outcomes.

\section{LAS - Leisure Attitude Scale (Portuguese version)}

The Leisure Attitude Scale (Freire \& Fonte, 2007) is composed of 36 items divided into three subscales for the three components of attitude - cognitive, affective and behavioral. Each subscale contains 12 items, all directed to the positive direction of attitude. The response system used is Likert, with five levels of related responses to agreement and disagreement, and 1 reveals an unfavorable or negative extreme attitude ("disagree") and 5 a favorable or positive extreme attitude ("totally agree"). Point 3 corresponds to a neutral level and the direction of the attitude ("Neither disagree nor agree"). Higher values (above the neutral point) show more positive attitudes and, on the contrary, the lower (below the neutral point) indicate more negative attitudes toward leisure. Thus, if the concept of attitude based on the three components is of particular relevance for the study of attitudes in general, it is also in the specific study of attitudes towards leisure since contributes to the investigation of psycho-social and socio-cognitive aspects of leisure, how to know and understand the degree and type of involvement of subjects. In leisure activities, as well as the forms and processes that underlie the change of attitudes towards leisure and quality of life, or to know the attitudes towards leisure in specific groups or contexts. Thus for each sub-scale the minimum possible total value is 12 and the maximum is 60 (neutral point located at 36). In relation to the total scale the minimum possible value is 36 and the maximum 180 (neutral point in the value 108).

\section{Sample Characterization}

The sample of the study is made up of 403 participants (valid questionnaires from a total of 620 respondents), between 53 and 93 years, with an average age of 72,9 years $(S D=8,43)$. The data has 150 men and 253 women. The subjects belonging to a rural area are 216, while the participants of an urban environment are 180. In the study sample, 356 subjects indicated that practice leisure activities, while 47 subjects do not. Regarding the perception of state of health, 332 subjects considered they self as independent $(82,6 \%)$ while 70 participants are considered dependent $(17,4 \%)$, as shown in Table 1. 
Table 1.

Sociodem ographic char acteristics $(N=403)$

\begin{tabular}{|c|c|c|c|c|c|c|c|c|c|}
\hline \multirow{2}{*}{$\begin{array}{c}\text { Age } \\
\text { Mean (SD) }\end{array}$} & & \multicolumn{2}{|c|}{ Gender } & \multicolumn{2}{|c|}{ Area } & \multicolumn{2}{|c|}{$\begin{array}{c}\text { Health } \\
\text { (perception) }\end{array}$} & \multicolumn{2}{|c|}{$\begin{array}{l}\text { Leisure activ. } \\
\text { (p ractice) }\end{array}$} \\
\hline & & $\mathbf{M}$ & $\mathbf{F}$ & Rural & Urban & Ind. & Dep. & Yes & No \\
\hline $72,9(8,43)$ & $N=$ & 150 & 253 & 216 & 180 & 332 & 70 & 356 & 47 \\
\hline
\end{tabular}

Participants are mostly married (47,6\%) or widowed (35,9\%). Qualifications, 153 participants have the $4^{\text {th }}$ class, 66 participants are illiterate and 70 have a higher qualification. When asked about the way they evaluate the health status, $43,2 \%(N=$ $174)$ indicate that "neither good, nor bad", but 40,1\% ( $N=164)$ evaluated as "good". Respondents subjects mostly do not live in any institution $(N=357 ; 88,6 \%)$, but 46 respondents are institutionalized $(11,4 \%)$.

Group Differences for Distress, Attitude for leisure and Well-being

It was tested the difference between the two sub-samples (leisure vs. without leisure) in Distress, Attitude for leisure and Well-being (Table 2).

Table 2 .

Differences between subjects with activities of leisure vs. no leisure (Distress, Attitude for leisure and Well-being)

Groups

\begin{tabular}{cc}
\hline Leisure & Without leisure \\
$(N=351)$ & $(N=46)$
\end{tabular}

$\begin{array}{llll}\text { Mean } & \text { Mean }\end{array}$

\begin{tabular}{lccccc}
\hline Attitude for Leisure & 152,49 & $(23,84)$ & 94,7 & $(35,65)$ & $10,679 *$ \\
\hline Distress & 4,48 & $(0,875)$ & 3,68 & $(0,986)$ & $5,654^{*}$ \\
Well-being & 3,92 & $(0,952)$ & 3,09 & $(0,934)$ & $5,672 *$ \\
& & & & & \\
\hline$p<, 01$
\end{tabular}


The sub-group that had leisure activities, presented high level of attitude for leisure $(t=10,679 ; p<0,01)$ and Well-being $(t=5,674 ; p<0,01)$. The subjects with high level of distress $(t=5,654 ; p<0,01)$ are involved in leisure activities. These subjects had found on leisure activities one method to decrease it.

\section{Group effect on the levels of Distress, Well-being and Attitude for Leisure (MANCOVA)}

Directly above are presented the results for the effect of the variable type of group in Distress, Well-being and Attitude for leisure, controlling the influence of Health Perception (co-variable). For the type of group (Table 3), it was tested a multivariate effect with statistical significance [Hotelling's Trace $=0,515 ; F_{(3: 341)}=58,516 ; p=0,00$ ].

Also a multivariate analysis of covariance (MANCOVA) revealed a significant effect of the co-variable Health Perception [Hotelling's Trace $=0,077 ; F_{(3 ; 341)}=8,733 ; p=0,00$ ] Testing a multivariate analysis of covariance (MANCOVA), the variable Health Perception was introduced as a covariate. The univariate analysis showed significant differences in Distress $\left[F_{(3 ; 341)}=17,055 ; p<0,01\right]$, Well-being $\left[F_{(3 ; 341)}=17437 ; p<0,01\right]$, and Attitude for leisure $\left[F_{(3 ; 341)}=171,583 ; p<0,01\right]$. More specifically, there were significant differences among the scales used (Table 3 ).

Table 3.

The Effect of Group in Distress, Well-being and Attitude for Leisure (MANCOVA)

\section{Groups}

\begin{tabular}{|c|c|c|c|c|c|c|}
\hline & \multirow{3}{*}{\multicolumn{2}{|c|}{$\begin{array}{l}\text { 1. Leisure } \\
(N=302)\end{array}$}} & \multirow{3}{*}{\multicolumn{2}{|c|}{$\begin{array}{l}\text { 2. Without leisure } \\
\qquad(N=44)\end{array}$}} & \multirow{4}{*}{$F^{*}$} & \multirow{4}{*}{ Post-Hoc } \\
\hline & & & & & & \\
\hline & & & & & & \\
\hline & Mean & (SD) & Mean & (SD) & & \\
\hline Distress & 4,47 & $(0,88)$ & 3,71 & $(0,98)$ & $17,055^{* *}$ & $1>2$ \\
\hline Well-being & 3,92 & $(0,95)$ & 3,12 & $(0,94)$ & $17,437^{* *}$ & $1>2$ \\
\hline Attitude for Leisure & 151,76 & $(24,05)$ & 94,73 & $(34,26)$ & $171,583 * *$ & $1>2$ \\
\hline \multicolumn{7}{|c|}{ Hoteling's Trace $=0,515 ; F_{(3 ; 341)}=58,516 ; p=0,00$} \\
\hline \multicolumn{7}{|c|}{ a Group Univariate Effect } \\
\hline \multicolumn{7}{|l|}{${ }^{b}$ Bonferroni Adis } \\
\hline \multicolumn{7}{|l|}{ Estimated means } \\
\hline${ }^{*} p<05 * *_{p<0} 01$ & & & & & & \\
\hline
\end{tabular}

Participants without activities of leisure had poorer punctuation on Well-being scale. Those participants also had worse scores on Attitude for leisure. 


\section{Discussion}

Results showed that people who were engaged in leisure activities have a more positive attitude towards the same. Higher results of Well-being were registered between people that are engaged with the leisure. This result is supported by the study of Heo et al. (2013) that compared the emotional adjustment at different stages. Psychological distress is higher when initiating a leisure activity.

Participants who register an independent health perception and high level of distress were involved in one leisure activity. The outcome is on the way of the work presented by Argimon et al. (2004). This result is also related with the study of Toyoshima, Kaneno and Motohashi, (2016) that revealed that the higher engagement in outdoor leisure activity was significantly related with a lower probability of psychological distress.

It was found seniors with high values of distress, the ones who get involved in activities, in order to decrease the levels of distress. This result is in the line of the approach of Chang et al. (2014).

Concerning the analysis of the multivariate effect, it was statistically significant $(p<0,01)$ with a significant univariate effect of the type of group in Attitude for leisure, Wellbeing and Distress $(p<0,01)$.

In our view, these results prove to be consistent as opposed to a conservative style of life without leisure activities. Integration of uncertainty in the various events of life and understanding its complexity requires not only a great cognitive flexibility, but also openness, exploration, receptivity to new ideas, perspectives and experiences.

\section{Conclusions}

Aging is characterized by a biological and psychosocial dynamic process. The development that the individual makes throughout his life confirms the process of its evolution, characterizing itself as a singular, unique and individual process.

This study aimed to sustain the importance to consider leisure as an income of aiding psychological well-being, avoiding distress among aged people. The attitude for leisure is also high leveled in subjects that have habitual activities of time-out and relaxation. Research supported the importance of screen, evaluate and control the distress in seniors. The psychosocial activity of leisure is considered an essential part in providing quality health. This may be even more visible in the case of subjects with high levels of distress, due to the lack of studies that demonstrate its impact on psychosocial well-being. In this sense, this work may contribute to a change in the context of the distress in the $3^{\text {rd }}$ and $4^{\text {th }}$ age. 
If the life of subjects in our study could be guided by an active participation in leisure activities, will allow them to comprehend others and, subsequently, improve positive feelings and behaviors, which can develop well-being and decrease distress.

Adjustment to leisure and the attitude for it, in particular, is a complex process that involves the participation in activities and it is important in all groups. It becomes even more important in old age and should provide the senior the opportunity to actively engage in an activity that provides their personal development. Leisure activities play a leading role in intellectual development, because it allows the obtaining of new knowledge, developing their critical thinking, joining new interpersonal relations, allowing a time to appreciate yourself, others and other cultures, expand their self-concept and still improve their quality of life.

In this sample, high levels of Distress, at time of diagnosis, could be predictive for future high levels of Attitude for leisure and Well-being. In terms of psychological benefits, these could improve the self-esteem, the image, the social contact and the feeling of pleasure with the life. In future studies it will be important to examine specific contexts of influence of leisure in distress and psychological well-being. Longitudinal investigations (cohort) that assess stability or change in participation in leisure activities will also be important. Maybe will be useful to study the relationship between social actions and quality of life in some different clusters of old age people to describe the particular impact in each.

In summary, the present study not only showed that leisure has a positive impact on the lives of the elderly, but these have both a high quality of life and a better attitude to continue participating in leisure activities. In addition, these are spaces of socialization that avoid social isolation, an occurrence present in the old aged population and which inversely correlate with optimal aging. Leisure has a positive impact for psychological well-being, promotes interpersonal relationships, and cultural knowledge. Activities that raise more longevity and a better physical action should consequently get more attention in the cycle of life. In short, the participation of older adults in this type of activities could be defined as a commitment for a positive experience.

\section{References}

Argimon, I. I. L., Stein, L. M., Xavier, F.M. F., \& Trentini, C. M. (2004). O impacto de atividades de lazer no desenvolvimento cognitivo de idosos. Revista Brasileira de Ciências do Envelhecimento Humano, 1(1), 38-47.

Belo, P., Pocinho, R., \& Navarro-Pardo, E. (2016). Analysis of the impact of leisure on well-being and distress in ageing. In F. J. García-Peñalvo (Ed.), Proceedings of the Fourth International Conference on Technological Ecosystems for Enhancing Multiculturality - TEEM'16 (pp. 425-429). ACM: New York, USA. doi: 10.1145/3012430.3012551

Brown, C. A., McGuire, F. A., \& Voelkl, J. (2008). The link between successful aging and serious leisure. International Journal of Aging \& Human Development, 66(1), 73-95. doi:10.2190/AG.66.1.d 
Belo, Pocinho \& Navarro-Pardo: Study of the leisure influence on attitude for leisure and mental health

Castro, V. C., \& Carreira, L. (2015). Leisure activities and attitude of institutionalized elderly people: a basis for nursing practice. Revista Latino-Americana de Enfermagem, 23(2), 307-314. doi:10.1590/01041169.3650 .2556

Chang, P. J., Wray, L., \& Lin, Y. (2014). Social Relationships, Leisure Activity, and Health in Older Adults. Health Psychology, 33(6), 516-523. doi:10.1037/hea0000051

Cheung, M. C., Ting, W., Chan, L. Y., Ho, K. S., \& Chan, W. M. (2009). Leisure participation and health related quality of life of community-dwelling elders in Hong Kong. Asian Journal of Gerontology \& Geriatrics, 4(1), 15-23.

Chodzko-Zajko, W.J., Proctor, D.N., Fiatarone Singh, M.A., Minson, C.T., Nigg, C.R., Salem, G.J., \& Skinner, J.S. (2009). American College of Sports Medicine position stand. Exercise and physical activity for older adults. Medicine \& Science in Sports \& Exercise, 41(7), 1510-1530. doi:10.1249/ MSS.0b013e3181a0c95c

Cohen, E. H. (2000). A facet theory approach to examining overall and life facet satisfaction relationships. Social Indicators Research, 51(2), 223-237. doi:10.1023/A:1007019526236

Fernández-Ballesteros, R. (2008). Active ageing. The contribution of psychology. Gottingën: Hogrefe \& Huber.

Freire, T. (2000). Ócio e tempo livre: Perspectivar o lazer para o desenvolvimento. Revista GalegoPortuguesa de Psicoloxia e Educación, 7(5), 345-349.

Freire, T., \& Fonte, C. (2007). Escala de atitudes face ao lazer em adolescentes e jovens adultos. Paidéia: Cadernos de Psicologia e Educação, 17(36), 79-87.

Glass, T. A., Mendes de Leon, C., Marottoli, R.A., \& Berkman, L. F. (1999). Population based study of social and productive activities as predictors of survival among elderly Americans. British Medical Journal, 319(7208), 478-483. doi:10.1136/bmj.319.7208.478

Hawkins, B., Foose, A. K., \& Binkley, A. L. (2004). Contribution of leisure to the life satisfaction of older adults in Australia and the United States. World Leisure Journal, 46(2), 4-12. doi:10.1080/0441905 7.2004 .9674353

Han, J., \& Patterson, I. (2007). An Analysis of the Influence That Leisure Experiences Have on a Person's Mood State, Health and Wellbeing. Annals of Leisure Research, 10(3-4), 328-351. doi: 10.1080/11745398.2007.9686770

Heo, J., Stebbins, R.A., Kim, J., \& Lee, I. (2013). Serious leisure, life satisfaction, and health of older adults. Leisure Sciences, 35, 16-32. doi:10.1080/01490400.2013.739871

Korten, A. E., Jorm, A. S., Jiao, Z., Letenneur, L., Jacomb, P. A., Henderson, A. S., ... \& Rodgers, B. (1999). Health, cognitive, and psychosocial factors as predictors of mortality in an elderly community sample. Journal of Epidemiology and Community Health, 53, 83-88. doi:10.1136/jech.53.2.83

Neter, J., Wasserman, W., \& Kutner, M.H. (1990). Applied Linear Statistical Models. Chicago: Richard D. Irwin, Inc

Osório, A. R. (2007). Os idosos na sociedade atual. In A.R. Osório \& F. C. Pinto (Eds.), As Pessoas Idosas. Contexto Social e Intervenção Educativa (pp. 1-73). Lisboa: Instituto PIAGET. 
Ra, J. M., Na, S., \& Rhee, K. (2013). The Relationship between Psychosocial Effects and Life Satisfaction of the Korean Elderly: Moderating and Mediating Effects of Leisure Activity. Journal of Arts and Humanities, 2(11), 21-35.

Ribeiro, J. P. (2001). Mental Health Inventory: Um Estudo de Adaptação à População Portuguesa. Psicologia, Saúde \& Doenças, 2(1), 77-99.

Schneider, R. H., \& Irigaray, T. Q. (2008). O envelhecimento na atualidade: aspectos cronológicos, biológicos, psicológicos e sociais. Estudos de Psicologia, 25(4), 585-593.

Shah, A., Wadoo, O., \& Latoo, J. (2010). Psychological distress in carers of people with mental disorders. Bristih Journal of Medical Practitioners, 3(3), a327.

Sun, R., \& Liu, Y. (2006). Mortality of the Oldest Old in China. Journal of Aging and Health, 18(1), 37-55. doi: $10.1177 / 0898264305281103$

Toyoshima, M., Kaneno, Y., \& Motohashi, Y. (2016). Leisure-time activities and psychological distress in a suburban community in Japan. Preventive Medicine Reports 4, 1-5. doi: 10.1016/j. pmedr.2016.04.007

Westland, C. (1991). Leisure and mental health. Recreation Canada, 49(4), 24-28.

Pedro Belo

Investigador da Universidade de Valencia. Mestre em Psicologia da Educação pela Universidade de Coimbra e doutorando de Psicogerontologia na Universidade de Valencia. Email: pedro.belo.santos@gmail.com

Ricardo Pocinho

Investigador do grupo INTERTECH-Valencia. Doutor em Educação pela Universidad de Salamanca e Doutor em Psicogerontologia pela Universidad de Valencia. Director de pós-graduação e formador na área do Envelhecimento. Reitor da Universidade Sénior do Mondego.

Esperanza Navarro-Pardo Investigadora do grupo INTERTECH-Valencia. Doutora em Psicologia pela Universidad de Valencia. Docente do Departamento de Psicologia da Universidade de Valencia.

\section{Corresponding Author Pedro Belo}

Department of Developmental and Educational Psychology. Universitat de València. Av. Blasco Ibáñez, 21. 46010, Valencia, Spain.

Data de submissão: Novembro de 2016

Data de avaliação: Abril de 2017 Data de publicação: Dezembro 2017 